\title{
Globalization and food insecurity in Middle East and North Africa: A panel cointegration and causality analysis
}

\author{
Yilmaz Bayar
}

Usak University, Usak, Turkey

\begin{tabular}{l} 
Keywords: \\
Globalization \\
Food \\
insecurity \\
Middle East \\
North Africa \\
Cointegration \\
\hline
\end{tabular}

Article history:

Received

14.03.2019

Received in

revised form

26.05.2019

Accepted

30.05.2019

\section{Corresponding author: \\ Yilmaz Bayar \\ E-mail: \\ yilmaz.bayar@ \\ usak.edu.tr}

DOI:

$10.24263 / 2310-$

1008-2019-7-1-15

\section{Abstract}

Introduction. It was researched the role of the globalization process in partial improvements in both undernourishment and hunger through decreasing the food insecurity in sample of Middle East and North Africa region over the 1999-2015 period.

Materials and methods. Westerlund and Edgerton (2007) cointegration test and Dumitrescu and Hurlin (2012) causality test were employed to analyze the short and long run impacts of various globalization types on the food insecurity.

Results and discussion. The cointegration coefficients revealed that trade globalization, financial globalization, social globalization, and political globalization negatively affected the prevalence of undernourishment. In other words, the components of globalization decreased the food insecurity in overall panel. However, trade globalization decreased the food insecurity in Djibouti, Egypt, Israel, Oman, Saudi Arabia, United Arab Emirates, and Yemen, but increased the food insecurity in Algeria, Iran, Iraq, Jordan, Lebanon, Morocco, and Tunisia. On the other side, financial globalization reduced the food security in Algeria, Iran, Iraq, Israel, Jordan, Lebanon, Morocco, Oman, Saudi Arabia, Tunisia, and United Arab Emirates reduced the food insecurity, while financial globalization had no significant effects on the food insecurity in Djibouti, Egypt, and Yemen. Furthermore, social globalization decreased the food security in Algeria, Iran, Iraq, Israel, Jordan, Lebanon, Morocco, Oman, Saudi Arabia, Tunisia, and United Arab Emirates and had no significant effects on food insecurity in Djibouti, Egypt, and Yemen. Lastly, political globalization reduced food insecurity in Algeria, Djibouti, Egypt, Iran, Iraq, Israel, Jordan, Lebanon, Oman, Saudi Arabia, Tunisia, and United Arab Emirates, but political globalization had no significant effects on the food security in Djibouti, Morocco, and Yemen. Furthermore, the causality analysis revealed a one-way causality from trade globalization/financial/political globalization to the food security, and a two-way causality between food security and social globalization. So, the main globalization types also had significant effects on the food insecurity in the short run.

Conclusions. The economic, social, and political globalization made a significant contribution to the relatively decreasing food insecurity in Middle East and North African region. 


\section{Introduction}

Food is the persons' most basic need together with water and essential to survive, grow, develop and maintain a healthfully life for all the human beings. In this regard, food security is commonly defined as the physical, economic, and social access of all the persons to adequate, safe and nutritive food for a healthy, productive and active life at any time and the main components of the food security are food availability, access, utilization, and stability [1,2]. In this context, provision of food security is essential for the human development, as one of the main components of growth and economic development of the nations [3]. Therefore, it is one of the leading priorities for the governments to plan and execute the right policies for the sufficient the food security level.

The undernourishment, malnourishment and hunger are the major results of the food insecurity. The globalized world experienced gradual improvements in the number of undernourished people and the number of people undernourished decreased 914.5 million in 1999 to 784.4 million in 2015, but the trend has seemed to become reversed and projected to be 820.8 million in 2017 and corresponded to about one out of every nine people in the world [4]. The determination of the causes underlying the food security is very important to take right measures in fight with food insecurity. In this regard, many institutional, social, economic, and political factors, poverty, and natural disasters (floods, droughts, earthquakes), and epidemic illnesses have been documented as the main drivers of the food insecurity.

Globalization process eliminated the boundaries to a large extent among the countries and raised the integration of economies in terms of goods, services and capital flows, also led the cultural, technological and political integration [5]. The benefits and costs of the globalization are one of the much-debated issues in the related literature. The scholars generally have focused the effect of globalization and major globalization types (e.g. financial globalization, trade globalization, political globalization, and social globalization) on the growth, financial sector development, poverty, inequality, environment $[6,7,8,9]$. However, globalization process may affect the food insecurity through increasing economic growth, efficiency, transfer of technology and know-how, the change of relative prices, price volatility, climate change, but the net influence of the globalization on the food insecurity depends on the sum of aforementioned factors' effects. Furthermore, increasing trade openness may raise the amount of food availability and range to the counties and thus make a contribution to the food security [10].

Middle East \& North African (MENA) region has a heterogeneous structure in terms of economic development and food insecurity as seen in Table 1. MENA region is one of the richest oil and gas reserves regions and made $45 \%$ of global crude oil exports and $31 \%$ of global liquefied natural gas in 2017 [11]. However, MENA region is the least peaceful region in the world [12]. The civil wars in Syria, Iraq, Libya, and Yemen has given damages to physical capital and human capital and in turn to the production. Further, the pressure imposed to the Qatar by Bahrain, Egypt, Saudi Arabia, and the UAE has raised the instability in the region. Also the economic and political instability, and internal conflicts in the region countries and the fluctuations in commodity prices are the major threats to the development of the countries. Algeria, Djibouti, Morocco, and Oman experienced significant improvements in the food security taking into account all of these. Only deteriorations were seen in the food security of Lebanon, Yemen and Jordan, but Iraq has high food insecurity levels majorly resulting from the raising civil war. Lastly, Egypt, Iran, Israel, Saudi Arabia, Tunisia, and UAE from the MENA region sustained their reasonable food insecurity levels. 
Prevalence of undernourishment and economic development in MENA region

\begin{tabular}{|c|c|c|c|c|}
\hline \multirow[t]{2}{*}{ Countries } & \multicolumn{2}{|c|}{ Prevalence of undernourishment } & \multicolumn{2}{|c|}{$\begin{array}{l}\text { Real gross domestic } \\
\text { product per capita }\end{array}$} \\
\hline & 1999 & 2015 & 1999 & 2015 \\
\hline Algeria & 10.7 & 4.7 & $10,248.75$ & $13,692.85$ \\
\hline Djibouti & 48.1 & 19.7 & $2,465.69$ & $3,015.13$ \\
\hline Egypt & 5.2 & 4.8 & $8,249.54$ & $11,308.58$ \\
\hline Iran & 4.9 & 4.9 & $12,463.25$ & $16,065.25$ \\
\hline Iraq & 28.3 & 27.7 & $\begin{array}{c}\text { Not } \\
\text { available }\end{array}$ & $14,429.99$ \\
\hline Israel & $<2.5$ & $<2.5$ & $24,803.00$ & $32,038.70$ \\
\hline Jordan & 12.6 & 13.5 & $7,061.78$ & $8,490.29$ \\
\hline Lebanon & $<2.5$ & 10.9 & $12,825.73$ & $17,553.62$ \\
\hline Morocco & 6.8 & 3.9 & $4,598.92$ & $7,554.50$ \\
\hline Oman & 11.9 & 5.4 & $39,338.85$ & $43,987.80$ \\
\hline Saudi Arabia & 6.1 & 5.5 & $42,371.76$ & $51,608.70$ \\
\hline Tunisia & 4.9 & 4.9 & $7,333.91$ & $10,765.87$ \\
\hline United Arab Emirates (UAE) & $<2.5$ & 2.5 & $95,012.82$ & $63,606.11$ \\
\hline Yemen & 29.9 & 34.4 & $3,769.32$ & $2,912.48$ \\
\hline
\end{tabular}

Source: $[13,14]$

The relevant literature revealed many economic, social, and institutional determinants of the food insecurity. However, the limited number of scholars have focused on the effect of accelerating globalization process as of late 1980s on the food security. The studies generally have researched the effect of trade openness or liberalization of agriculture sector on the food security as seen in literature review section. However, the globalization is a multifaceted process and not only trade globalization but also financial globalization, social globalization, and political globalization may affect the food insecurity. In this study, we aim making a contribution to the relevant literature by focusing on the untouched area and using second generation econometric tests considering the cross-sectional dependence and heterogeneity in relevant literature. Within this scope, our sample is MENA region, because MENA region experienced a similar globalization pattern with the world as seen in Figure 1 and the region also is one of the least food insecure regions in the world.

The rest of the article is constructed as the following. The forthcoming part briefly summarizes the relevant literature on the effect of globalization on the food security. Then the dataset and empirical analysis method are defined, and the empirical analyses are performed and the main findings of the analyses are presented. Lastly, the conclusions are presented. 


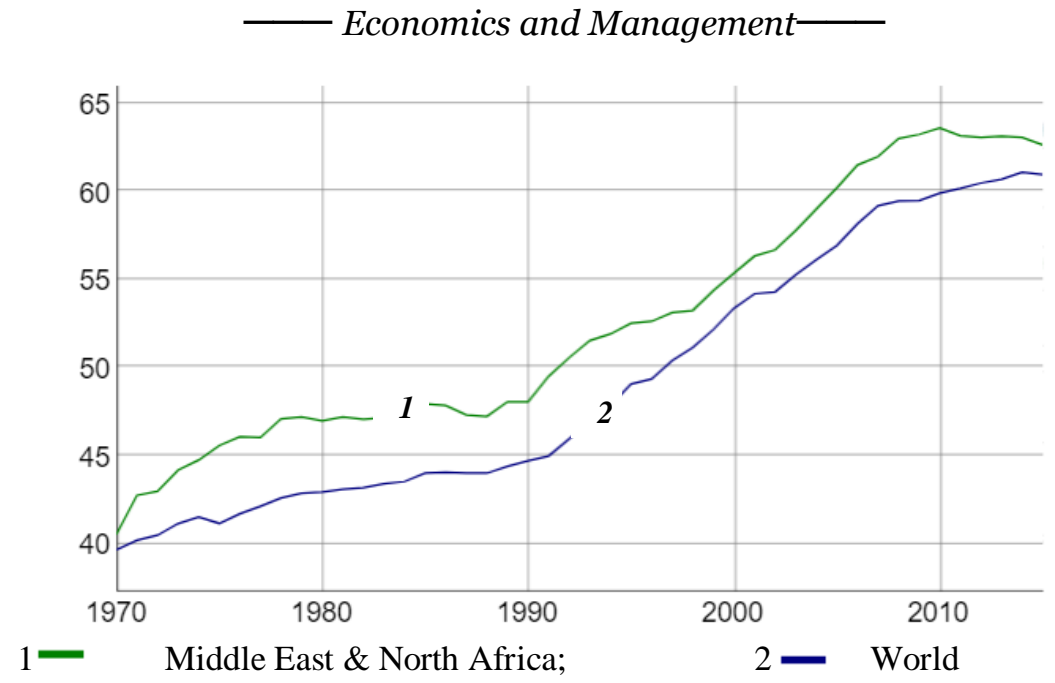

Figure 1. KOF globalization index of MENA and world

Source: KOF Swiss Economic Institute, 2018

\section{Literature review}

Food security and its implications are one of the most discussed and to be sought for solution in the globalized world. Globalization process, the crucial development of the past four decades, have potential to affect the food insecurity through its main components food access, availability, utilization, and stability by raising the economic growth, efficiency, and mobility of goods, services, and capital, transfer of technology and know-how, the change of relative prices, price volatility, and change of climate and environment. As a result, the interaction between types and implications of globalization and food insecurity have been researched widely until now, but most of the studies focus on theoretical considerations about food security [e.g. see 15, 16, 17]. Only a limited number of scholars have empirically researched the effect of globalization represented by agricultural trade openness and trade openness on the food security and reached mixed findings as described below.

In one of the studies, [18] investigated the influence of trade liberalization on the food security in India with general equilibrium model and revealed that both growth and poverty reduction resulting from trade liberalization did not raise the food security. [19] researched the effect of agricultural trade openness on the food security in Sub-Saharan Africa by a dynamic general equilibrium model and the analysis revealed that the net effects of agricultural trade openness over the food security changed depending on comparative advantage at sectoral level.

[20] researched the effect of trade liberalization on the food availability in 37 developing countries, and revealed that trade liberalization negatively affected the food availability in the short run, but trade liberalization had no significant effects on the food availability in the long run. On the other side, [21] analyzed the effect of trade openness on the food security in Sri Lanka and China over the 1980-2009 period with regression analysis and discovered no significant relationship between food security and trade openness in China, but a negative relationship for Sri Lanka.

[22] examined the influence of trade openness on the food security in 151 countries during the 1980-2007 period with regression analysis and discovered that trade openness 


\section{- Economics and Management-}

increased the food security in the panel. [23] analyzed the influence of trade openness on the food security with 41 policy reforms by synthetic control method over 1960-2010 period and revealed that trade liberalization decreased the food insecurity in 19 cases, increased food insecurity in 3 cases. [24] researched the impact of agricultural trade openness on food security in Iran over the period 1999-2013 with ARDL approach and revealed that agricultural trade openness raised the food security in Iran in the long run. Lastly, [25] researched the influence of regional integration over the food security in ECOWAS countries by panel regression analysis over the 1995-2012 period and revealed that international trade affects the food security positively, but regional integration had no significant effects on food security.

\section{Data and econometric methodology}

\section{Data}

In the empirical analysis, food insecurity was represented with prevalence of undernourishment calculated by Food and Agriculture Organization of the United Nations (FOA) and it reflects the share of the population who cannot consume sufficient amount of calories to cover their energy requirement for an active and healthy life. There have been different indicators showing the food security such as Global Food Security Index of Economist Intelligence Unit, and prevalence of severe food insecurity in the total population of FOA. But we selected indicator of undernourishment prevalence, because the other indicators showing the food security exists for relatively too shorter periods.

On the other side, globalization was proxied by globalization index of KOF Swiss Economic Institute. The Institute calculates the composite index based on economic, social, and political dimensions (see [5] for detailed information about the index). In the study, two components of economic globalization including trade globalization and financial globalization and social globalization and political globalization, because trade globalization and financial globalization are the featured aspects of the globalization process and also the related literature generally have concentrated on the effect of trade liberalization on the food security. Further, de facto indexes of trade and financial globalization were used, because they are calculated based on the flows of inter-country goods, services, and capital and the globalization indices generally base on de facto globalization, while de jure trade and financial globalization indexes are calculated based on trade taxes and regulations, investment restrictions, tariffs, and capital account openness. The economic globalization including trade globalization and financial globalization reflects the raising interdependence of the economies arising from the growing cross-border flows of goods, services, capital and rapidly spread of the technologies [26]. Social globalization consists of transnational movement of cultures, while political globalization reflects the raising political cooperation among the countries [27].

Table 2

\section{Data description}

\begin{tabular}{|c|c|c|}
\hline Variables & Description & Source \\
\hline FOODINSEC & Prevalence of undernourishment (\%) & {$[13]$} \\
\hline TG & Trade globalization, de facto index & {$[28]$} \\
\hline FG & Financial globalization, de facto index & {$[28]$} \\
\hline SG & Social globalization index & {$[28]$} \\
\hline PG & Political globalization index & {$[28]$} \\
\hline
\end{tabular}




\section{- Economics and Management-}

The data availability determined the sample and time duration of the study. The sample is composed of 14 states from MENA region (Algeria, Djibouti, Egypt, Iran, Iraq, Israel, Jordan, Lebanon, Morocco, Oman, Saudi Arabia, Tunisia, United Arab Emirates, and Yemen except Bahrain, Kuwait, Libya, Qatar, Syria, West Bank and Gaza). The time duration was 1999-2015 and all the data were annual. The econometric analysis were conducted by software of E-views 10.0 and Gauss 10.0 and Stata 14.0. The main characteristics of the dataset were shown in Table 3. The mean of food insecurity level in the panel is about 11.3, but the highest level was 48.1, and the lowest level was about 1.5 and the standard deviation was 10 .

\section{Main characteristics of the dataset}

Table 3

\begin{tabular}{|c|c|c|c|c|c|}
\hline & FOODINSEC & TG & FG & SG & PG \\
\hline Mean & 11.31131 & 60.58867 & 55.01497 & 52.03005 & 67.74370 \\
\hline Median & 6.100000 & 62.31761 & 55.30032 & 54.28485 & 67.49583 \\
\hline Maximum & 48.10000 & 96.50836 & 92.62033 & 74.22993 & 93.41541 \\
\hline Minimum & 1.500000 & 10.68345 & 14.07935 & 22.69474 & 27.93740 \\
\hline Std. Dev. & 10.07732 & 18.84615 & 17.75916 & 14.52326 & 15.60165 \\
\hline Skewness & 1.455990 & -0.317382 & -0.125680 & -0.201320 & -0.255629 \\
\hline Kurtosis & 4.008895 & 2.891854 & 2.775700 & 1.744227 & 2.104507 \\
\hline
\end{tabular}

\section{Econometric methodology}

[29] cointegration test rests on the Lagrange multiplier (LM) developed by [30] and takes notice of cross-sectional dependence among the series. The cointegration test statistic $\left(L M_{N}^{+}\right)$ is calculated as following:

$$
L M_{N}^{+}=\frac{1}{N T^{2}} \sum_{i=1}^{N} \sum_{t=1}^{T} \widehat{w}_{i}^{-2} s_{i t}^{2}
$$

The partial sum of error terms $\left(s_{i t}^{2}\right)$ and long term variances $\left(\widehat{w}_{i}^{-2}\right)$ is derived from cointegration model estimated by full modified ordinary least squares model. The null hypothesis supporting the presence of cointegration is tested by $L M_{N}^{+}$and critical values generated by bootstrap method are utilized in the event of cross-sectional dependence. Furthermore, the test gives robust results in case of small samples due to the implemented Monte Carlo simulations. The cointegration coefficients were estimated by DSUR (Dynamic Seemingly Unrelated Cointegrating Regression) estimator of [31] considering the presence of cross-sectional dependence.

Lastly, the causal relation among food insecurity and main components of globalization was analyzed by [32] causality test rest on VAR. The test considers heterogeneity, but assumes cross-sectional independence. However, the Monte Carlo simulations denoted that the test can produce robust results even in the event of cross-sectional dependence. [32] causality test provides individual Wald statistics $\left(W_{i, T}\right)$ for each cross-section and then calculates panel Wald statistic by taking arithmetic mean of the cross-sections. [32] suggest that $Z_{N, T}^{H N C}$ test statistic with asymptotic distribution should be used in case of $\mathrm{T}>\mathrm{N}$, while $Z_{N}^{H N C}$ test statistic with semi- asymptotic distribution should be used in case of $\mathrm{N}>\mathrm{T}$. 


$$
\begin{gathered}
Z_{N, T}^{H N C}=\sqrt{\frac{N}{2 K}}\left(W_{N, T}^{H N C}-K\right) \\
Z_{N}^{H N C}=\frac{\sqrt{N}\left[W_{N, T}^{H N C}-N^{-1} \sum_{i=1}^{N} E\left(W_{i, T}\right)\right]}{\sqrt{N^{-1} \sum_{i=1}^{N} \operatorname{var}\left(W_{i, T}\right)}}
\end{gathered}
$$

\section{Empirical analysis}

The presence of cross-sectional dependence among the series of food insecurity and globalization components was investigated by [33] LM test and [34] LM adjusted test, since time dimension was higher than cross-section dimension and the test results were demonstrated in Table 4. The null hypothesis of cross-section independence was declined in consideration of $\mathrm{p}$ values. So we inferred the presence of cross-section dependence. Then homogeneity of the cointegration coefficients was tested with adjusted delta tilde test of [35] and the results were shown in Table 4. The cointegration coefficients were found to be heterogeneous in consideration of $\mathrm{p}$ values of the test.

Cross-sectional dependency and homogeneity tests' results

Table 4

\begin{tabular}{|c|c|c|}
\hline \multicolumn{3}{|c|}{ Cross-sectional dependence tests } \\
\hline Test & Test statistic & Prob. value \\
\hline LM test & 32.781 & 0.001 \\
\hline$L M_{\text {adj }}$ test & 39.066 & 0.002 \\
\hline \multicolumn{3}{|c|}{ Homogeneity tests } \\
\hline Test & Test statistic & Prob. value \\
\hline Delta_tilde & 8.909 & 0.001 \\
\hline Delta_tilde_adj & 7.653 & 0.016 \\
\hline
\end{tabular}

The stationarity of the variables were explored after pre-tests of cross-sectional dependence and homogeneity. The cross sectional Augmented Dickey-Fuller (CADF) unit root test of [36] regarding the presence of cross-sectional dependence, was employed to examined the availability of unit root in the variable series and the test results were demonstrated in Table 5. Maximum lag length was applied as 2 and Schwarz information criterion was considered in determination of optimal lag length. The results revealed that all the variables were non-stationary, but became stationary after first-differencing.

Panel CIPS unit root test results

Table 5

\begin{tabular}{|c|c|c|c|c|}
\hline & \multicolumn{2}{|c|}{ Level } & \multicolumn{2}{c|}{ First differences } \\
\hline Variables & Constant & Constant + Trend & Constant & Constant + Trend \\
\hline FOODINSEC & -1.184 & -1.166 & $-7.531^{*}$ & $-9.744^{*}$ \\
\hline TG & -1.230 & -1.202 & $-9.556^{*}$ & $-9.902^{*}$ \\
\hline FG & -0.973 & -1.105 & $-7.099^{*}$ & $-8.126^{*}$ \\
\hline SG & -0.877 & -1.083 & $-6.451^{*}$ & $-7.449^{*}$ \\
\hline PG & -1.141 & -1.156 & $-7.834^{*}$ & $-8.238^{*}$ \\
\hline
\end{tabular}

* it is significant at $5 \%$ significance level 
The existence of cointegration relationship among food security and main components of the globalization was explored by [29] LM bootstrap cointegration test and the test results were demonstrated in Table 6. Further, bootstrap probability values were generated from 10000 simulations and asymptotic $\mathrm{p}$-values were obtained from standard normal distribution. Lag and leads were taken as 2. Bootstrap critical values were taken in consideration due to the presence of cross-sectional dependence. Hence, the null hypothesis stating the presence of cointegration was accepted. So all the series move together in the long run.

Table 6

LM Boostrap cointegration test results

\begin{tabular}{|c|c|c|c|c|c|c|}
\hline \multirow{4}{*}{$L M_{N}^{+}$} & \multicolumn{4}{|c|}{ Constant } & \multicolumn{3}{c|}{ Constant+Trend } \\
\cline { 2 - 7 } & $\begin{array}{c}\text { Test } \\
\text { statisti } \\
\mathrm{c}\end{array}$ & $\begin{array}{c}\text { Asymptoti } \\
\mathrm{c} \mathrm{p} \text {-value }\end{array}$ & $\begin{array}{c}\text { Bootstra } \\
\mathrm{p} \mathrm{p}- \\
\text { value }\end{array}$ & $\begin{array}{c}\text { Test } \\
\text { statisti } \\
\mathrm{c}\end{array}$ & $\begin{array}{c}\text { Asymptoti } \\
\text { c p-value }\end{array}$ & $\begin{array}{c}\text { Bootstra } \\
\mathrm{p} \mathrm{p} \text { - } \\
\text { value }\end{array}$ \\
\cline { 2 - 7 } & 0.893 & 0.161 & 0.287 & 6.924 & 0.004 & 0.381 \\
\hline
\end{tabular}

The cointegration coefficients were forecasted by DSUR estimator taking notice of the presence of cross-sectional dependence and heterogeneity and the test results were demonstrated in Table 7.

Table 7

Estimation of cointegrating coefficients

\begin{tabular}{|l|c|c|c|c|}
\hline \multirow{2}{*}{ Countries } & \multicolumn{4}{|c|}{ Coefficients } \\
\cline { 2 - 5 } & TG & FG & SG & PG \\
\hline Algeria & $0.192^{*}$ & $-0.275^{*}$ & $-0.151^{*}$ & $-0.381^{*}$ \\
\hline Djibouti & $-0.074^{*}$ & 0.175 & $0.144^{*}$ & -0.251 \\
\hline Egypt & $-0.095^{*}$ & 0.284 & $0.219^{*}$ & $-0.386^{*}$ \\
\hline Iran & $0.187^{*}$ & $-0.187^{*}$ & $-0.247^{*}$ & $-0.337^{*}$ \\
\hline Iraq & $0.214^{*}$ & $-0.155^{*}$ & $-0.213^{*}$ & $-0.293^{*}$ \\
\hline Israel & $-0.364^{*}$ & $-0.128^{*}$ & $-0.085^{*}$ & $-0.065^{*}$ \\
\hline Jordan & $0.108^{*}$ & $-0.062^{*}$ & $-0.208^{*}$ & $-0.188^{*}$ \\
\hline Lebanon & $0.085^{*}$ & $-0.091^{*}$ & $-0.149^{*}$ & $-0.231^{*}$ \\
\hline Morocco & $0.137^{*}$ & $-0.136^{*}$ & $-0.165^{*}$ & 0.276 \\
\hline Oman & $-0.275^{*}$ & $-0.228^{*}$ & $-0.125^{*}$ & -0.218 \\
\hline Saudi Arabia & $-0.254^{*}-0.381^{*}$ & $0.254^{*}$ & $-0.351^{*}$ \\
\hline Tunisia & $0.091^{*}$ & $-0.104^{*}$ & $-0.201^{*}$ & $-0.053^{*}$ \\
\hline United Arab Emirates & $-0.374^{*}$ & $-0.299^{*}$ & $-0.191^{*}$ & $-0.375^{*}$ \\
\hline Yemen & $-0.119^{*}$ & 0.162 & $0.083^{*}$ & 0.229 \\
\hline Panel & $\mathbf{- 0 . 2 1 7 *}$ & $\mathbf{- 0 . 2 3 5 *}$ & $\mathbf{- 0 . 2 0 8 *}$ & $-\mathbf{0 . 2 4 9 *}$ \\
\hline
\end{tabular}




\section{- Economics and Management-}

The results indicated that trade globalization, financial globalization, social globalization, and political globalization negatively affected the prevalence of undernourishment. In other words, the components of globalization decreased the food insecurity in overall panel. However, trade globalization decreased the food insecurity in Djibouti, Egypt, Israel, Oman, Saudi Arabia, United Arab Emirates, and Yemen, but increased the food insecurity in Algeria, Iran, Iraq, Jordan, Lebanon, Morocco, and Tunisia. On the other side, financial globalization reduced the food security in Algeria, Iran, Iraq, Israel, Jordan, Lebanon, Morocco, Oman, Saudi Arabia, Tunisia, and United Arab Emirates reduced the food insecurity, while financial globalization had no significant effects on the food insecurity in Djibouti, Egypt, and Yemen. Furthermore, social globalization decreased the food security in Algeria, Iran, Iraq, Israel, Jordan, Lebanon, Morocco, Oman, Saudi Arabia, Tunisia, and United Arab Emirates and had no significant effects on food insecurity in Djibouti, Egypt, and Yemen. Lastly, political globalization reduced food insecurity in Algeria, Djibouti, Egypt, Iran, Iraq, Israel, Jordan, Lebanon, Oman, Saudi Arabia, Tunisia, and United Arab Emirates, but political globalization had no significant effects on the food security in Djibouti, Morocco, and Yemen.

The barriers over cross-country flows of goods, services, and capital have been considerably released and also cross-country foreign direct investments and portfolio investments, in turn transfer of technology and know-how have been raised significantly. However, frequency and severity and contagiousness of the economic and financial crises, change of relative prices and price volatility, climate and environment deteriorations have been experienced relatively more when compared with the past. So on one hand, globalization process can raise food security by increasing food availability and access, economic growth through efficiency, transfer of technology and know-how and provision of financing and better public management. On the other hand, globalization can increase the food insecurity through raising frequency and severity and contagiousness of the economic and financial crises, change of relative prices and price volatility, climate and environment deteriorations. As a consequence, the net effect of globalization and its main types over food insecurity can vary from country to country. Our empirical analysis revealed that globalization and its major components decreased the food insecurity in most of countries in the sample. However, trade globalization raised the food insecurity in countries of Algeria, Iran, Iraq, Jordan, Lebanon, Morocco, and Tunisia which experienced serious civil wars, internal disturbances, embargo, and weak economic fundamentals. Furthermore, financial and political globalization had no significant effect on the food insecurity in Yemen experiencing serious civil war, in Djibouti with weak economic fundamentals and public management,

The causal interaction among food security and the components of globalization were examined with [32] causality and the test results were demonstrated in Table 8. The results revealed a one-way causality from trade globalization/financial/political globalization to the food security, and a two-way causality between food security and social globalization. So, the main globalization types also had significant effects on the food insecurity in the short run. 
Causality test results

\begin{tabular}{|c|c|c|c|}
\hline Null hypothesis & Test & Statistics & Prob. \\
\hline \multirow[t]{3}{*}{ FOODINSEC $\nrightarrow$ TG } & Whnc & 1.296 & 0.287 \\
\hline & Zhnc & 1.442 & 0.293 \\
\hline & Whnc & 1.075 & 0.195 \\
\hline \multirow{3}{*}{ TG $\nrightarrow$ FOODINSEC } & Whnc & 4.732 & 0.000 \\
\hline & Zhnc & 5.029 & 0.000 \\
\hline & Ztild & 4.726 & 0.001 \\
\hline \multirow[t]{3}{*}{ FOODINSEC $\nrightarrow F G$} & Whnc & 0.954 & 0.187 \\
\hline & Zhnc & 0.833 & 0.291 \\
\hline & Ztild & 0.907 & 0.125 \\
\hline \multirow[t]{3}{*}{ FG $\nrightarrow$ FOODINSEC } & Whnc & 3.732 & 0.000 \\
\hline & Zhnc & 2.877 & 0.001 \\
\hline & Ztild & 3.023 & 0.003 \\
\hline \multirow[t]{3}{*}{ FOODINSEC $\nrightarrow$ SG } & Whnc & 4.202 & 0.000 \\
\hline & Zhnc & 3.761 & 0.002 \\
\hline & Ztild & 5.281 & 0.025 \\
\hline \multirow[t]{3}{*}{ SG $\nrightarrow$ FOODINSEC } & Whnc & 4.384 & 0.000 \\
\hline & Zhnc & 3.945 & 0.001 \\
\hline & Ztild & 4.113 & 0.000 \\
\hline \multirow[t]{3}{*}{ FOODINSEC $\nrightarrow \mathrm{PG}$} & Whnc & 1.287 & 0.274 \\
\hline & $Z h n c$ & 1.375 & 0.256 \\
\hline & Ztild & 0.988 & 0.197 \\
\hline \multirow[t]{3}{*}{ PG $\nrightarrow$ FOODINSEC } & Whnc & 5.606 & 0.000 \\
\hline & Zhnc & 3.734 & 0.011 \\
\hline & Ztild & 4.563 & 0.008 \\
\hline
\end{tabular}

\section{Conclusion}

The undernourishment, malnourishment and hunger have been the serious problems of the humankind resulting from the food insecurity. However, improvements in both undernourishment and hunger have been experienced partially together with accelerating globalization as of 1990s. However, most of the studies theoretically analyzed the interaction between globalization, especially trade openness/agricultural trade openness and food security in the related literature, but the number of empirical studies about the globalizationfood insecurity nexus has remained restricted. This study investigates the roles of various globalization types on the food insecurity in Middle East and North African countries over the period 1999-2015 with panel cointegration and causality analyses considering the untouched area in the relevant literature.

The empirical analysis revealed that trade, financial, social, and political globalization generally made a significant contribution to the relatively decreasing food insecurity in Middle East and North African region in both short and long run. So, the benefits of globalization outweigh the costs in terms food insecurity. However, MENA region includes very heterogeneous countries in terms of economic and institutional development, demographic, religious, and social structure, and natural resources (especially oil and natural 


\section{- Economics and Management-}

gas). Furthermore, the region is also the least peaceful part of the world and some countries (e.g. Yemen, Iraq, and Lebanon) are experiencing serious civil wars, while the others (e.g. Morocco, Saudi Arabia, and Tunisia) had serious internal conflicts, political instability, and weak economic fundamentals. Lastly, the variations in the prices of oil and natural gas seriously affect the economies of oil and gas-rich countries. Consequently, the effect of major globalization types on food security can be raised by the countries to take measures to increase the peaceful environment and decrease the dependence of the countries on the energy.

\section{References}

1. Food and Agriculture Organization of the United Nations (1996), World Food Summit, Available at: http://www.fao.org/docrep/003/w3613e/w3613e00.htm

2. Food and Agriculture Organization of the United Nations (2006). Food Security, Available at:

http://www.fao.org/fileadmin/templates/faoitaly/documents/pdf/pdf_Food_Security_ Cocept_Note.pdf

3. World Bank (2006), Repositioning nutrition as central to development: A strategy for large-scale Action, Washington.

4. Food and Agriculture Organization of the United Nations (2018a), The State of Food Security and Nutrition in the World: Building Climate Resilience for Food Security and Nutrition, Rome

5. Gygli S., Haelg F., Sturm J.E. (2018), The KOF Globalisation Index - Revisited. KOF Working Papers, No. 439, Available at: https://www.researchcollection.ethz.ch/handle/20.500.11850/238666 (18.11.2018)

6. van Veen-Groot D.B., Nijkamp P. (1999), Globalisation, transport and the environment: New perspectives for ecological economics, Ecological Economics, 31(3), pp. 331-346, DOI: 10.1016/S0921-8009(99)00099-3

7. Wade R.H. (2004), Is globalization reducing poverty and inequality? World Development, 32(4), pp. 567-589, DOI: 10.1016/j.worlddev.2003.10.007

8. $\quad$ Ying Y.H., Chang K., Lee C.H. (2014), The impact of globalization on economic growth, Romanian Journal of Economic Forecasting, 27(2), pp. 25-34.

9. Zahonogo P. (2018), Globalization and economic growth in developing countries: Evidence from Sub-Saharan Africa, International Trade Journal, 32(2), pp. 189-208, DOI:10.1080/08853908.2017.1333933

10. Guha-Khasnobis B., Acharya S.S., Davis B. (2007), Food security indicators, measurement, and the impact of trade openness, Oxford University Press WIDER Studies in Development Economics Series.

11. BP (2018), BP Statistical Review 2018, Available at: https://www.bp.com/content/dam/bp/en/corporate/pdf/energy-economics/statisticalreview/bp-stats-review-2018-middle-east-insights.pdf

12. Institute for Economics \& Peace (2018), Global Peace Index 2018, Measuring Peace in a Complex World, : http://visionofhumanity.org/reports

13. Food and Agriculture Organization of the United Nations (2018b), Food Security Indicators, http://www.fao.org/economic/ess/ess-fs/ess-fadata/en/\#.W_EJLegzZPY

14. World Bank (2018), GDP per capita (constant 2010 US\$), https://data.worldbank.org/indicator/NY.GDP.PCAP.KD ) 


\section{- Economics and Management-}

15. Kaufmann C., Heri S. (2007), Liberalizing trade in agriculture and food securityMission impossible? Vanderbilt Journal of Transnational Law, 40, pp. 1039-1070.

16. Mukherji I.N. (2014), Agricultural trade liberalization for food security in South Asia. United Nations Economic and Social Commission for Asia and the Pacific (ESCAP) Development Papers 1404.

17. Stefanis C. (2014), Global food security: An agricultural perspective. Journal of Agriculture and Sustainability, 6(1), pp. 69-87.

18. Panda M., Kumar A.G., (2009), Trade liberalization, poverty, and food security in India, IFPRI Discussion Paper 00930.

19. Chikhuri K. (2013), Impact of alternative agricultural trade liberalization strategies on food security in the Sub-Saharan Africa region, International Journal of Social Economics, 40(3), pp. 188-206, DOI:10.1108/03068291311291491

20. Bezuneh M., Yiheyis Z. (2014), Has trade liberalization improved food availability in developing countries? An empirical analysis, Journal of Economic Development, 39(1), pp. 63-68.

21. Herath H.M.S.P. (2014), Has trade liberalization improved food security? A comparative study on China and Sri Lanka. European Journal of Business and Management, 6(18), pp. 62-67.

22. Dithmer J., Abdulai A. (2017), Does trade openness contribute to food security? A dynamic panel analysis, Food Policy, 69, pp. 218-230, DOI:10.1016/j.foodpol.2017.04.008

23. Olper A., Curzi D., Swinnen J.F.M. (2017), Trade liberalization and child mortality: A synthetic control method. LICOS Discussion Paper Series, No. 387, LICOS, Leuven

24. Arsalan B., Hamid M. (2018), The effect of agriculture trade openness on food security in Iran (ARDL Approach), Journal of Agricultural Economics Research, 10(2), pp. 81-103.

25. Tinta A.A., Sarpong D.B., Ouedraogo I.M., Hassan R.A., Mensah-Bonsu A., Onumah E.E. (2018), The effect of integration, global value chains and international trade on economic growth and food security in ECOWAS, Cogent Food \& Agriculture, 4, pp. 1-15, DOI: 10.1080/23311932.2018.1465327

26. Shangquan G. (2000), Economic globalization: Trends, risks and risk prevention, Available at:

http://www.un.org/en/development/desa/policy/cdp/cdp_background_papers/bp2000 _1.pdf

27. Goryakin Y., Lobstein T., James P.T., Suhrckeb M. (2015), The impact of economic, political and social globalization on overweight and obesity in the 56 Low and Middle Income countries, Social Science \& Medicine, 133, pp. 67-76, DOI: 10.1016/j.socscimed.2015.03.030

28. KOF Swiss Economic Institute (2018), KOF globalisation index, https://www.kof.ethz.ch/en/forecasts-and-indicators/indicators/kof-globalisationindex.html

29. Westerlund J., Edgerton D.L. (2007), A panel bootstrap cointegration test, Economics Letters, 97(3), pp. 185-190, DOI: 10.1016/j.econlet.2007.03.003

30. McCoskey S., Kao C. (1998), A residual-based test of the null of cointegration in panel data, Econometric Reviews, 17(1), pp. 57-84.

31. Mark, N.., Ogaki M., Sul D. (2005), Dynamic seemingly unrelated cointegrating regressions. Review of Economic Studies, 72(3), pp. 797-820. 
32. Dumitrescu E.I., Hurlin C. (2012), Testing for Granger non-causality in heterogeneous panels, Economic Modelling, 29(4), pp. 1450-1460, DOI:10.1016/j.econmod.2012.02.014

33. Breusch T.S., Pagan A.R. (1980), The lagrange multiplier test and its applications to model specification tests in econometrics, Review of Economic Studies, 47, pp. 23953.

34. Pesaran M.H., Ullah A., Yamagata T. (2008), A bias-adjusted LM test of error crosssection independence, Econometrics Journal, 11(1), pp. 105-127.

35. Pesaran M. H., Yamagata, T. (2008), Testing slope homogeneity in large panels, Journal of Econometrics, 142, pp. 50-93.

36. Peseran M.H. (2007), A simple panel unit root test in the presence of cross-section dependency, Journal of Applied Econometrics, 22, pp. 265-312. 